\title{
Testicular Yolk Sac Tumor, Myxomatous Pattern
}

National Cancer Institute

\section{Source}

National Cancer Institute. Testicular Yolk Sac Tumor, Myxomatous Pattern. NCI

Thesaurus. Code C39929.

A yolk sac tumor that arises from the testis and is characterized by the presence of

myxomatous tissue that contains collections of malignant cells with prominent nucleoli. 